\title{
Study of the Problem of Rising Groundwater levels in Aswan City Area
}

\author{
Manal, A. Moneim ${ }^{1}$, Eman, R. Nofal ${ }^{2 *}$ \\ Research Institute for Groundwater, National Water Research Centre, El Kanater El Khairiya, 13621, Egypt
}

\begin{abstract}
Aswan city, southern part of Egypt, is currently suffering from rising groundwater levels since 2009 due to partial discontinued pumping in some main well fields and growing urbanization in high relief areas; causing severe environmental problems hindering development activities. The present study aims to examine the changes in groundwater levels in the city using recorded data from 2012 to 2017. Numerical groundwater flow modeling is used to simulate the hydrogeological conditions of the region. Hence, the calibrated model is run to examine the solution of lowering groundwater. Inversing the groundwater rising process in the model is achieved by applying imposed abstraction rates, from eight well fields, equal to that before the rising levels problem. The adopted solution succeeded to nullify the rise in groundwater levels. However, further studies are recommended to evade negative geotechnical impacts so that the final design of an engineered solution can be set and physically implemented.
\end{abstract}

Keywords: Groundwater management, Groundwater modeling, Groundwater de-watering, Nile Valley.

DOI: $10.7176 /$ CER/12-9-06

Publication date:September 30th 2020

\section{Introduction}

The study area of Aswan City lies within the Aswan Governorate in the southern part of Egypt. It is bounded by longitude $32^{\circ} 52^{\prime \prime}$ to $32^{\circ} 56^{\prime \prime} \mathrm{E}$ and latitude $24^{\circ} 01^{\prime \prime}$ to $24^{\circ} 06^{\prime \prime} \mathrm{N}$ at the east bank of Nile River (Figure 1 ). The city is currently suffering from groundwater rising problem, which is a major environmental problems that hinders the city development. The problem is clearly observed in several main areas of the city, such as; Kima area, Al-Shalal, the army buildings, the health insurance hospital and blood bank building, El Giesh street, and the Television building area.

Rising of groundwater is believed to have taken place since 2009, after pumping from the water Company's well field in Al-Shalal area was partially ceased due to pollution from septic tanks, where its pumping rate is decreased to $34,560 \mathrm{~m} 3 /$ day. In the meantime, pumping rates from the Kima 40 wells was decreased from a total of 36,744 $\mathrm{m}^{3} /$ day to about $25000 \mathrm{~m}^{3} /$ day. Figure 2 shows examples of areas affected by the groundwater rising problem all over the Aswan city.

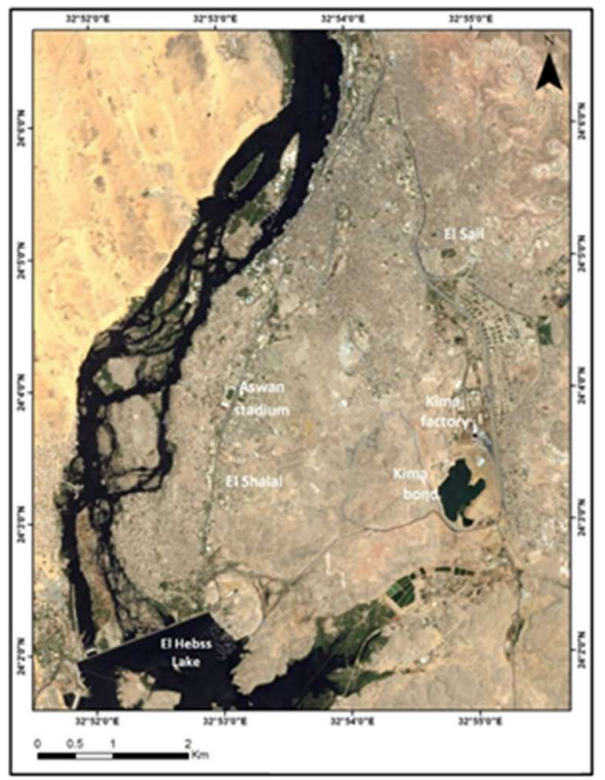

Figure 1. Location map of the study area. 
The present study aims to examine the changes in groundwater levels in the study area during the period from 2012 to 2017. The data is acquired from the observation wells network implemented in the study area by the Research Institute for Groundwater, Aswan governorate and the Company for Water and Sanitation, through two subsequent research projects during this period. These projects were executed to simulate the hydrogeological conditions of the region using numerical models to examine the solution of lowering groundwater levels back to the original conditions before the groundwater rising problem.
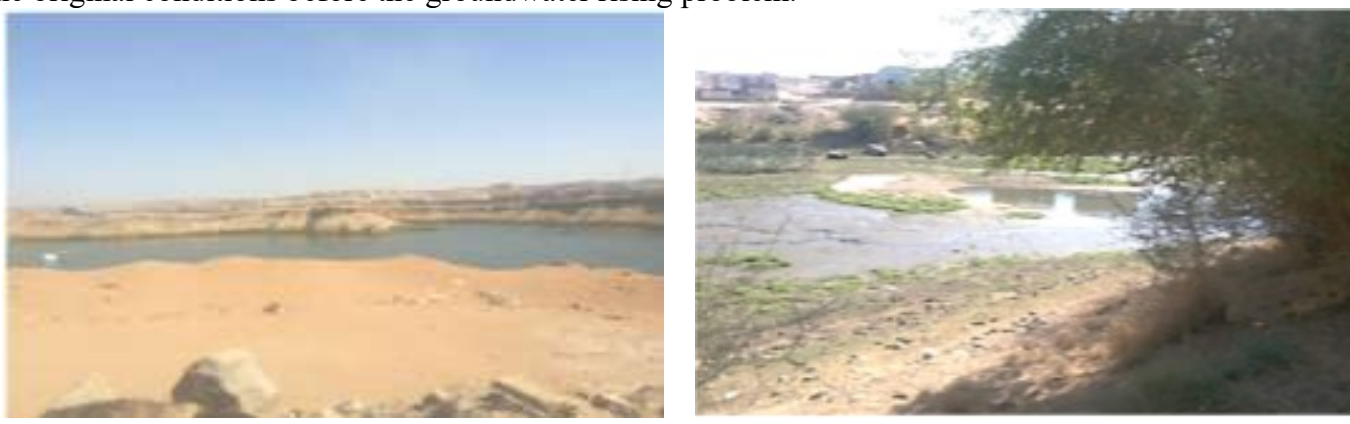

Figure 2. Examples of areas affected by the groundwater rising problem.

\section{The Study Area}

\subsection{Climate}

The climate of the study area is arid to extremely arid; the maximum temperature varies from $23^{\circ} \mathrm{C}$ in January to $41^{\circ} \mathrm{C}$ in July. The rainfall is rare and may reach $1 \mathrm{~mm} /$ year. Evaporation rates reach a maximum value of about $170 \mathrm{~mm} /$ year in the summer season.

\subsection{Topography}

The study area takes a pear shape with a length of $10 \mathrm{~km}$ and its width ranges between $8.6 \mathrm{~km}$ in south to $1 \mathrm{~km}$ in north. Its topography varies from $85 \mathrm{~m}$ above mean sea level in the north direction to $111 \mathrm{~m}$ above mean sea level in the southern direction. Figures (3) and (4) show the topographic contour map and cross sections in both E-W and N-S direction.

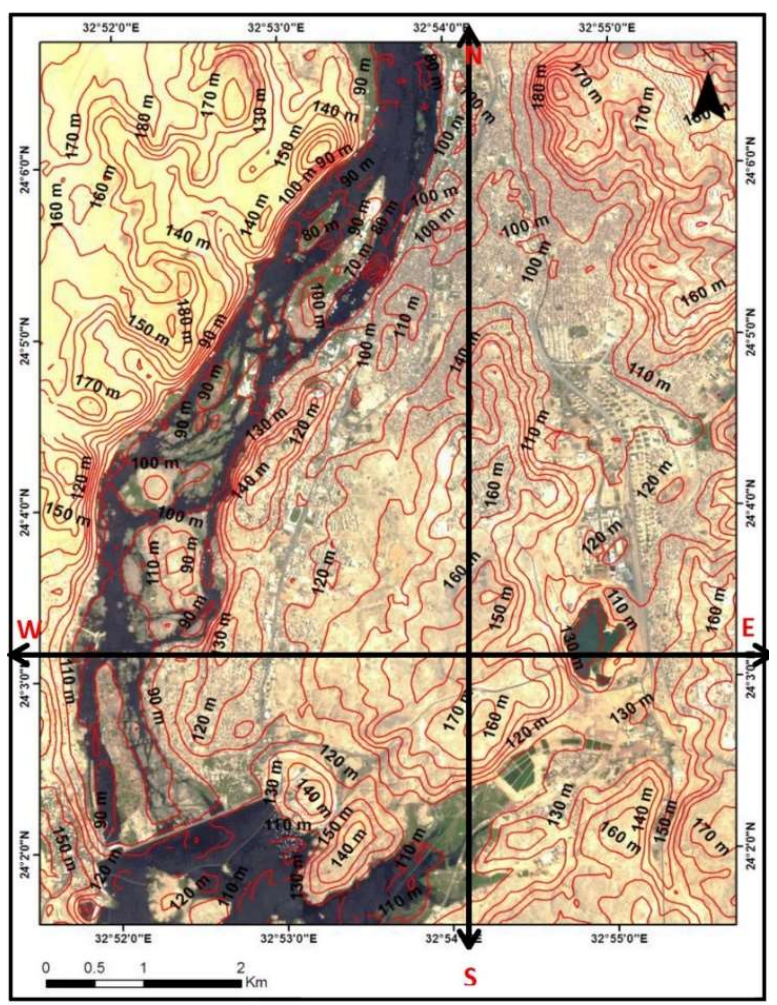

Figure 3. Topographic map of the Aswan City. 

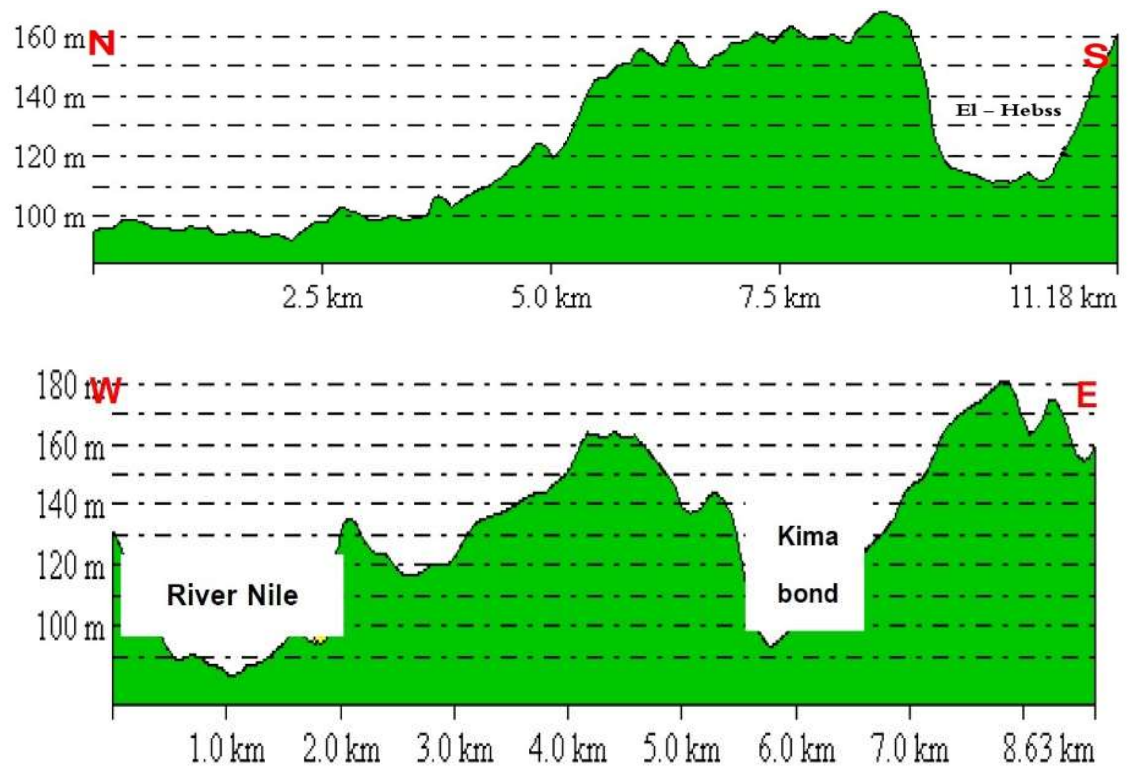

Figure 4. Topographic cross-sections (North-South) (West- East).

\subsection{Geomorphology}

The study area comprises three main geomorphic units as follows:

i. High Lands: It is steep and relatively high lands. The more extensive high lands is located east of the study area (180 AMSL). In the central part of the study area, all the mountains are formed of basement rocks, such as El Shiekh Haroon Mountain (163m) in northern part, Tagog Mountain (140m) in the western part and Granite Mountain $(167 \mathrm{~m})$ in the middle.

ii. Low Lands (Young alluvial plains): It is the recent plains, which are located along the Nile River in the northern part of the city, where the agricultural lands and most of the residential neighborhoods exist especially to the west. These plains consist of silt and clay deposits of the Holocene period. These areas are characterized by variation in topography ranging from $111 \mathrm{~m}$ in the south to $85 \mathrm{~m}$ in the north.

iii. Surface Water System: It consists of the Nile River in the western part of the study area with elevation 106 AMSL, while Aswan dam covers the southern part with an elevation of 118 AMSL.

\section{Geology}

The geology of the study area (Fig. 5) has been described by Said (1962 \& 1981), Barber and Carr (1981), Issawi and Jux (1982), and others. The main geologic units exposed in the study area are summarized as follows:

- The Precambrian rocks are formed of a complex of igneous and metamorphic rocks, mainly granites and schists. It surrounds the study area from the east and west sides. They lie beneath the Nubian sandstone formations.

- The Nubian sandstone; ranges in age from the Cambrian to the Cretaceous and overlay the basement rocks, with a total thickness ranges between 20 and $85 \mathrm{~m}$ (Attia 1954).

- The Quaternary sediments are exposed in the middle part of the study area with a general increase from south to north. They are represented by sands, gravels, and clay, underlain by a thick bed of Pliocene clays (RIGW 1988). 


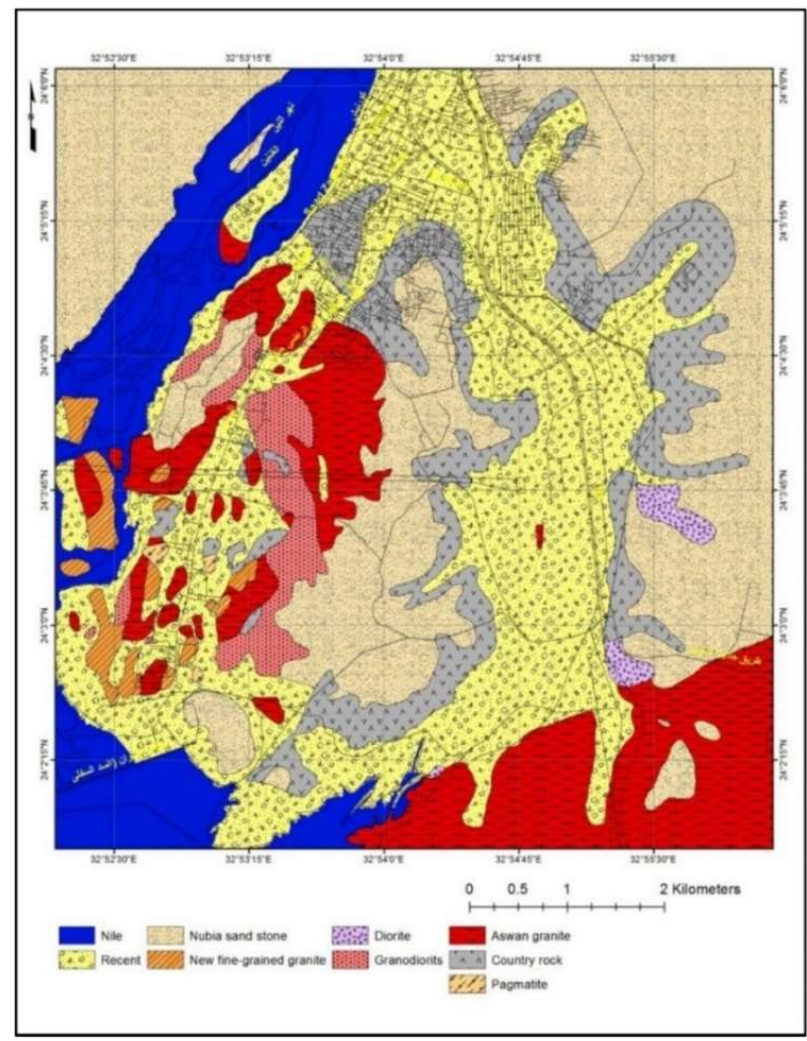

Figure 5. Geological map of the study (CONCO, 1987).

\section{Hydrogeology}

\subsection{The Aquifer System}

The Quaternary aquifer is the main groundwater aquifer in Aswan city; it is mainly composed of unconsolidated sands, gravels, and clays intercalation. Its thickness varies from 100 to $120 \mathrm{~m}$ at Aswan city. The eastern and western borders of the aquifer are bounded by the basement rocks. The quaternary aquifer is underlined by a clay layer of Pliocene age that extended to a depth of about $248 \mathrm{~m}$, with a general increase from south to north (based on Kima well lithology). The aquifer is not covered by the impermeable layers in the study area; therefore, it is under unconfined condition. (Selim S., 1995 and Hamdan, 2013).

The depth to groundwater varies from $0.74 \mathrm{~m}$ in the western part to $22 \mathrm{~m}$ in the southern part of the study area at Kima, and it is affected by the topography of the study area. The general flow of groundwater is from south to north direction i.e.; from high to low lying areas.

\subsection{Aquifer Recharge and Discharge}

The recharge of the Quaternary aquifer in the study area comes mainly from the following sources:

- Direct percolation from the Aswan Dam Reservoir, where the water level ranges between 106 and 118 , depending on the discharge from the high dam,

- Seepage from excess water irrigation (flooding irrigation) in El Shalal area,

- Seepage from septic tanks due to the lack of sewage system.

Groundwater discharge is taking place through pumping groundwater for industrial and domestic uses. One of the main consumers of groundwater is the Aswan Water Company where there is continuous withdrawal, mostly in Kima and El Shalal areas. The average rates of groundwater withdrawal and the number of wells during the period from 2009 to 2017 is illustrated in table (1). 
Table 1. Groundwater withdrawal through the period from 2009 to 2017

\begin{tabular}{|l|l|l|l|l|l|}
\hline \multirow{2}{*}{ No } & Groundwater discharge & Number of & \multicolumn{3}{|c|}{ Discharge Rate (m3/day) } \\
\cline { 4 - 6 } & & Wells & 2009 & 2012 & 2017 \\
\hline 1 & Water company wells & 40 & 34,560 & 0 & 0 \\
\hline 2 & Kima company wells & 40 & 36,744 & 25,000 & 25,000 \\
\hline & Total & 80 & 71304 & 25,000 & 25,000 \\
\hline
\end{tabular}

\section{The Problem of Groundwater Rising}

The city of Aswan is currently suffering from the problem of groundwater rising which is considered as a severe environmental problem hindering development activities in the city. The problem is believed to have taken place as a result of alteration of the balanced recharge-discharge conditions in the aquifer system. The problem has been manifested after pumping from the water Company's well field in Al-Shalal area was partially ceased because of pollution from septic tanks, and the partial discontinued pumping from the Kima wells. To study the problem of rising groundwater levels, thirty five observation wells were drilled in the study area during the period from 2012 to 2017. Construction of the observation wells started with 7 wells in 2012 and then followed by additional 28 in 2017. The observation wells, as shown in figure (6), were used to monitor groundwater levels and to identify the sources of recharge. In order to assess the problem, data on depth to groundwater, groundwater level, ground elevation, and well depth were collected from the production wells and monitoring wells in all affected areas.

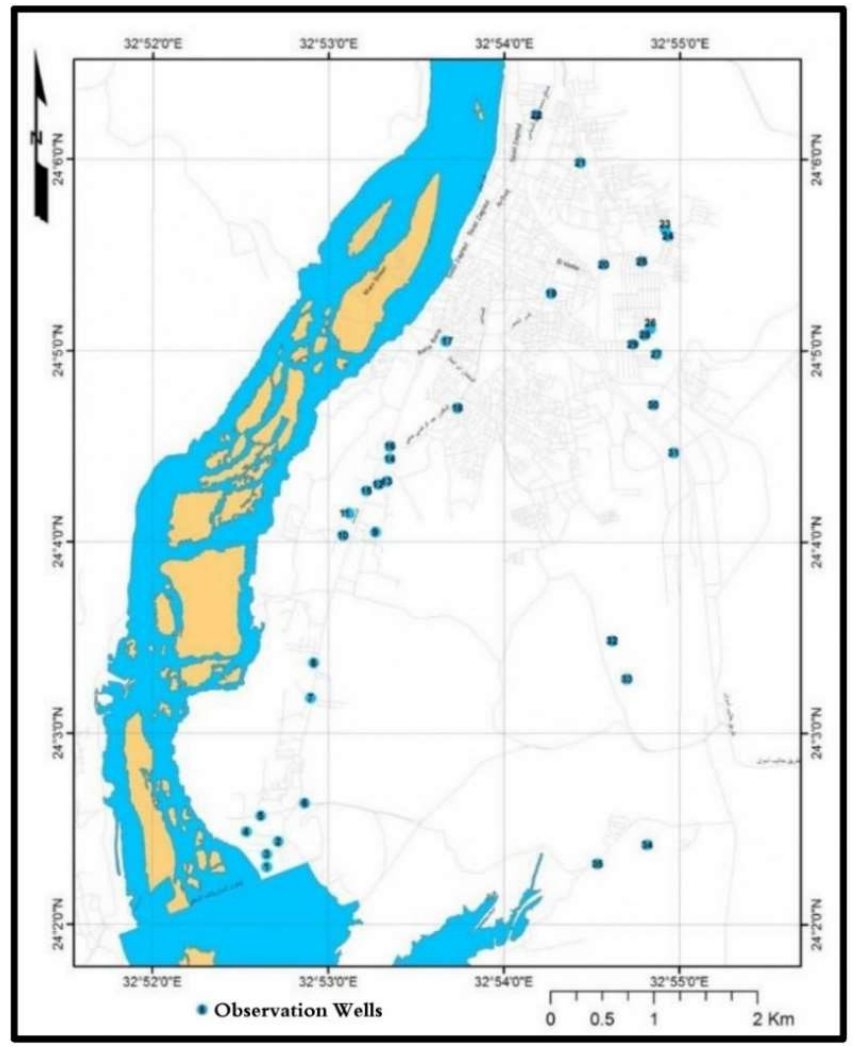

Figure 6. Location of observation wells.

The collected data is used to construct a contour map of groundwater levels for the year 2017, figures 7 . Change in groundwater levels during the period from 2012 to 2017 varied from $0.25 \mathrm{~m}$ to $5.9 \mathrm{~m}$, as illustrated in figure (8). Investigation and analysis of hydrogeologic conditions in the study area indicate that groundwater rising is mainly attributed to reduction of pumping from both the Kima and El Shalal Area well fields, seepage from excess irrigation water in El Shalal area, seepage from municipal waste water due to growing urbanization in surrounding areas of high relief, and seepage from the fish hatchery bonds in the south part of study area. 
Furthermore, sixteen surface and groundwater samples were collected and analyzed chemically and microbiologically. The total dissolved solids (TDS) varied from 445 to $3365 \mathrm{ppm}$ in most of the city. The analyses revealed that TDS in Kima area has increased from 565 to $1700 \mathrm{ppm}$ as result of surface pollution. However, TDS for the deep wells varied from 262 to $385 \mathrm{ppm}$. On the other hand, TDS reached to up to18660 ppm in the polluted bonds. Generally, TDS increases in the northern part of the study area and decrease to the south (el Shalal area), due to bad drainage conditions prevailing in the cultivated areas. In addition, analysis of the total coliforms and fecal coliforms are found to reach 550 and $400 \mathrm{CFU} / 100 \mathrm{ml}$, respectively, which indicate the presence of a microbiological pollution due to seepage from the sewage system.

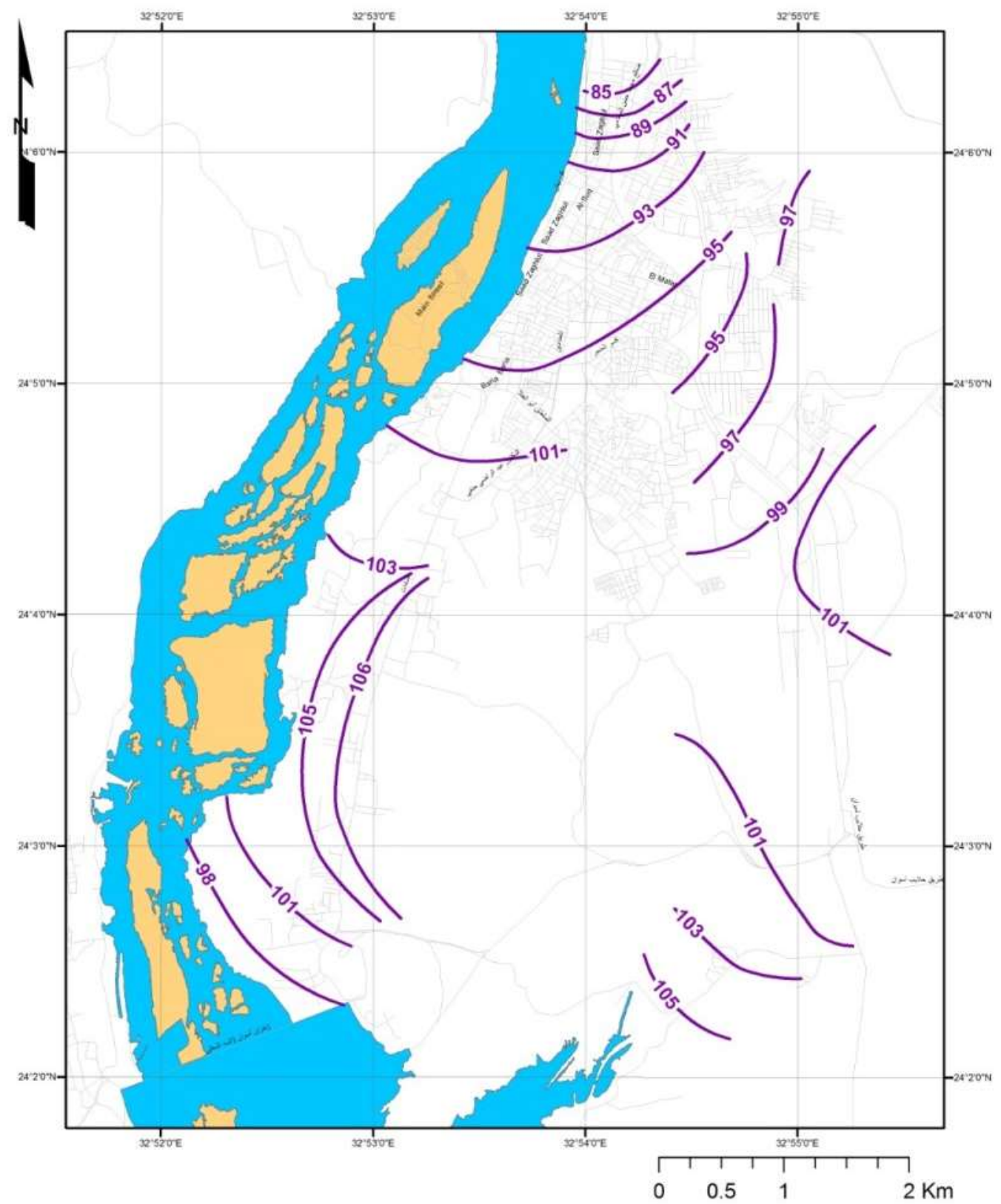

Figure 7. Contour map of groundwater levels for the year 2017. 


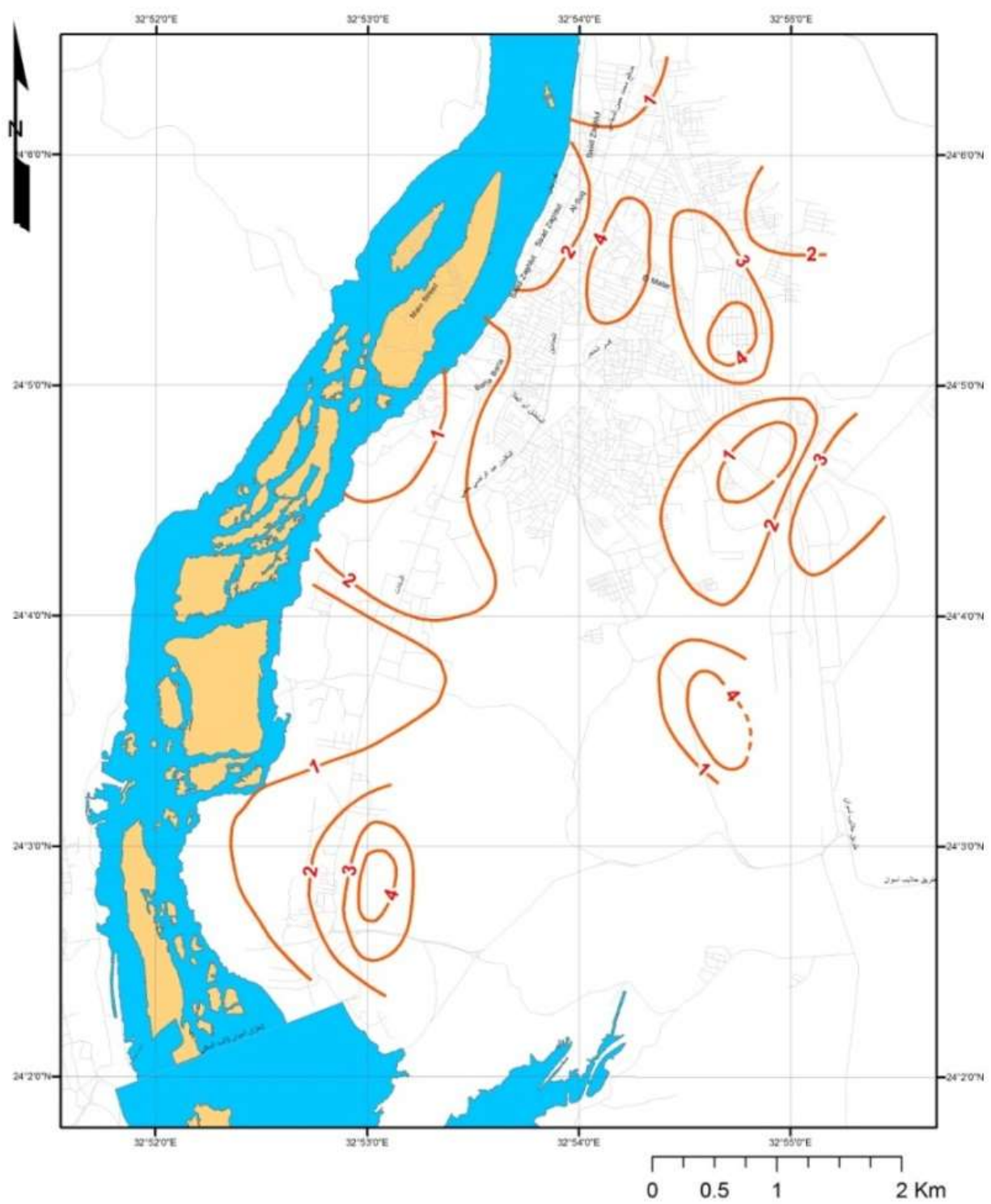

Figure 8. Rise in groundwater levels during the period from 2012 to 2017.

\section{Numerical Simulation Modeling}

\subsection{Model Objective}

Numerical groundwater modeling is used to simulate aquifer conditions and to predict the effects of hydrological changes. The large-scale regional groundwater systems are simulated using various user-friendly modelling effective tools. In this study, a three-dimensional finite difference modelling package namely "Visual MODFLOW4.6" is used to simulate the hydrogeological system in the study area. Based on the identified groundwater rising problem in the study area, in terms of the changes of groundwater levels during the period from 2012 to 2017 and the spatial distribution of these changes, the numerical simulation model is used as an interpretative tool for investigating the groundwater system dynamics; and as an assessment tools for analyzing responses of the groundwater system to stresses. This is with the objective to simulate inversing the groundwater levels rising process to examine the possibility of bringing groundwater levels back to the original conditions before the problem.

\subsection{Model Setup}

Data collected during the field investigations and from the literature have been used to simulate the groundwater 
flow in the study area. The modeled area is about $88 \mathrm{Km}^{2}$. The model grid (Figure 9) consists of a one layered $110 \mathrm{X} 80$ cells covering the model area, each cell has an area of $100 \mathrm{~m}^{2}$.

Boundary conditions are mathematical statements specifying the head or fluxes of the problem domain. Correct selection of the boundary conditions is a critical step in the model setup. As per the model boundary conditions, the western and southern boundaries were represented by the River Nile and assigned as "constant head", the northern boundary assigned as "constant head", and the eastern boundary was selected along the physical boundary of granite rock and this boundary was represented as a "no flow boundary".

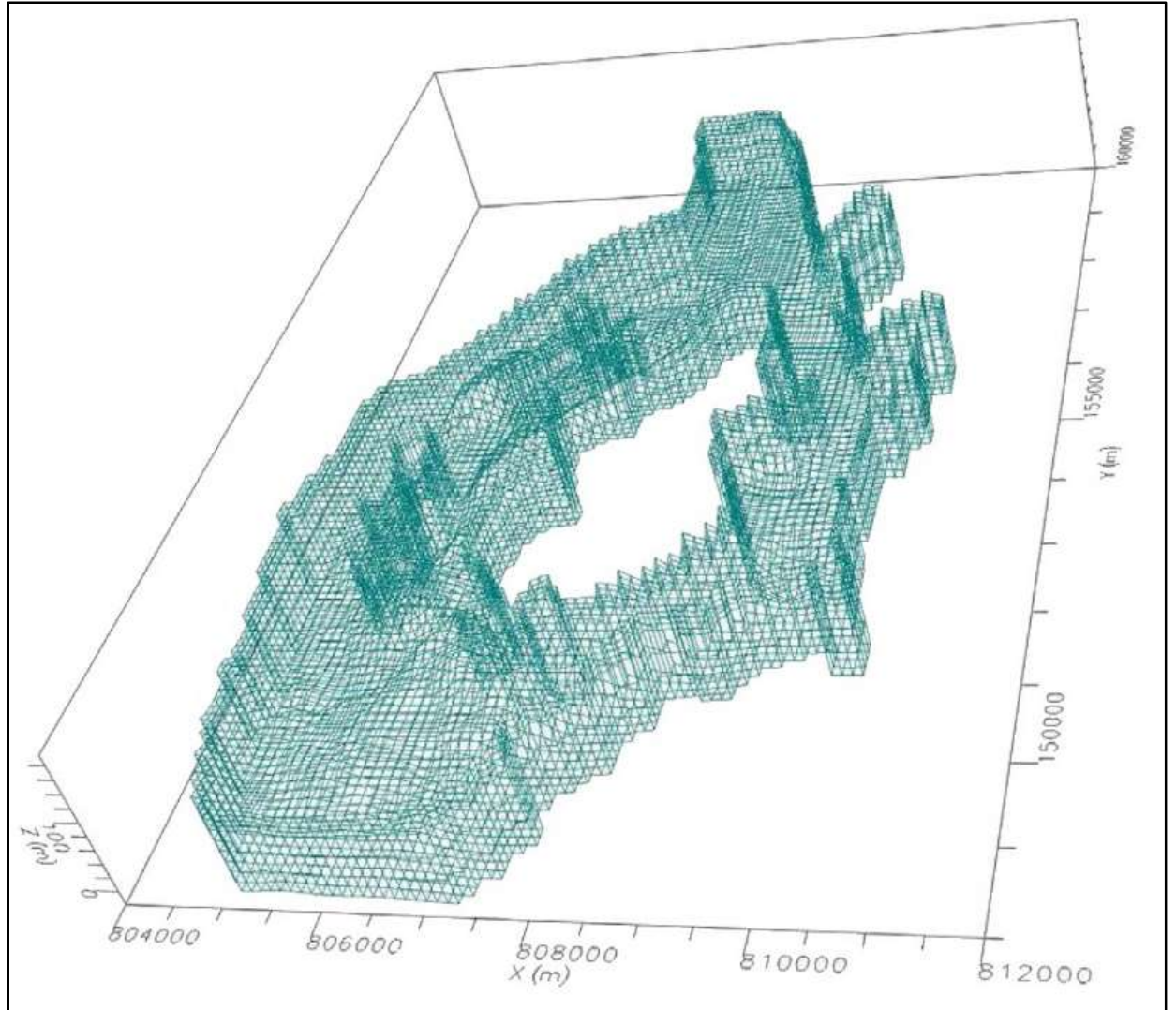

Figure 9. Grid of the modeled area.

\subsection{Model Calibration}

The Calibration Process is executed into two steps: 1) the first step is the steady state calibration for the numerical model against the historical piezometric heads; 2) The second step is the unsteady state calibration for the numerical model during the period from 2012 to 2017 . The calibration process has been done through several trials by adjusting the recharge parameters and hydraulic conductivity to generate piezometric heads, which are in agreement with the measured ones. Comparison between the calculated and observed groundwater levels is shown in figure (10). The model calibrated piezometric heads for the year 2017 are shown in figure (11). 


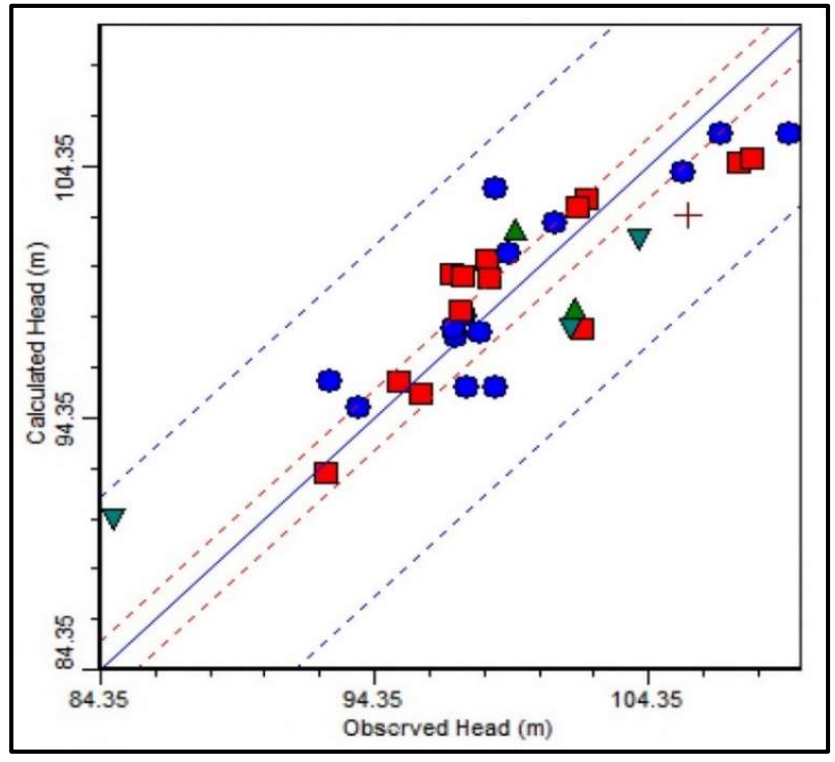

Figure 10. Calculated versus observed groundwater heads (calibration 2017).

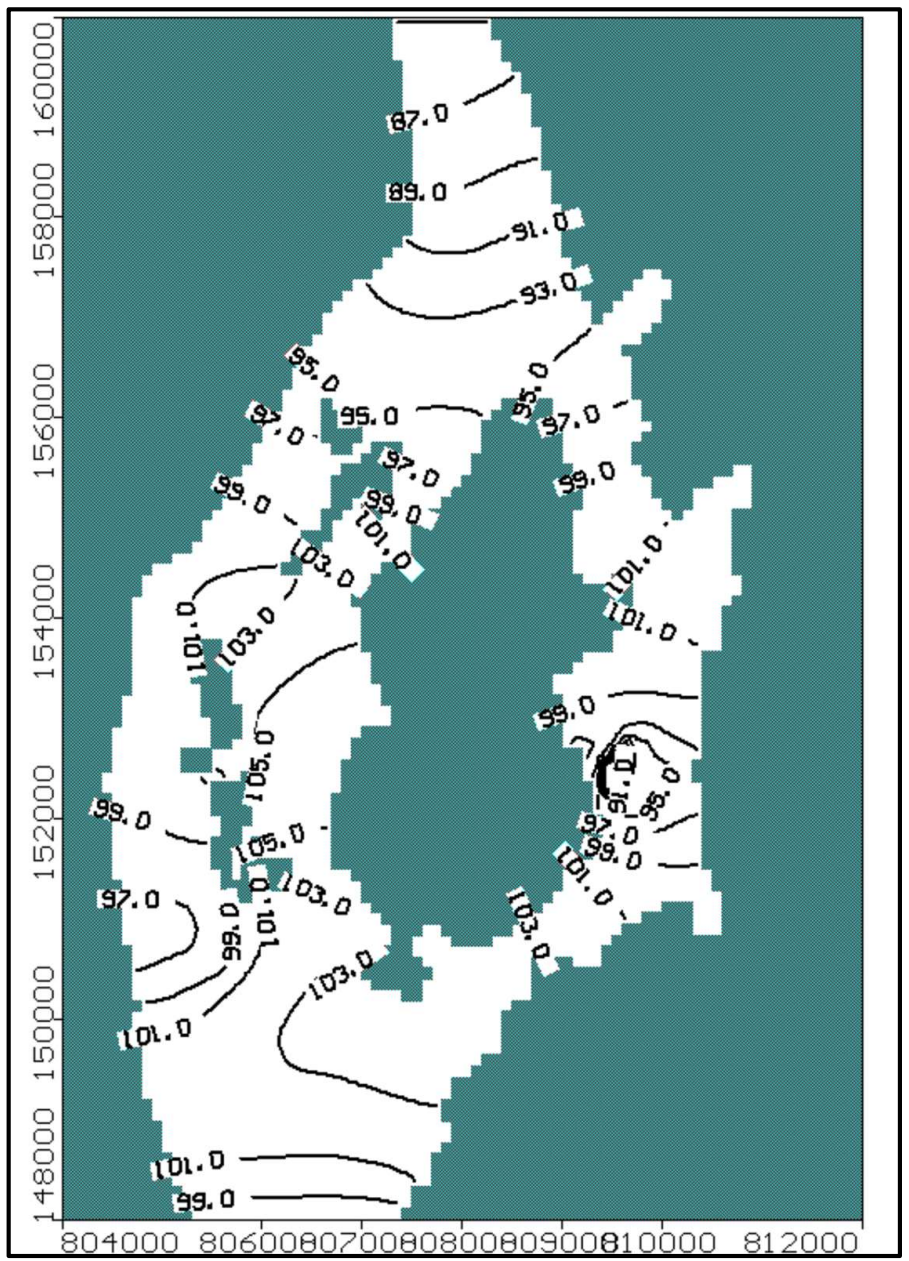

Figure 11. Calibrated piezometric heads for study area at 2017. 


\subsection{Proposed Solution}

The proposed solution is to introduce a dewatering system by pumping wells in the study area, with the objective of lowering the groundwater levels so that these levels are brought back to the original conditions before the problem. Accordingly, eight abstraction sites distributed in the affected areas are considered in the model as shown in figure (12). The model imposed abstraction in selected eight locations is determined so that the total abstraction from the study area is brought back equal to that before the groundwater rising problem. Hence, the imposed abstraction rate in the model is set equal to $4,000 \mathrm{~m}^{3} /$ day from each abstraction site.

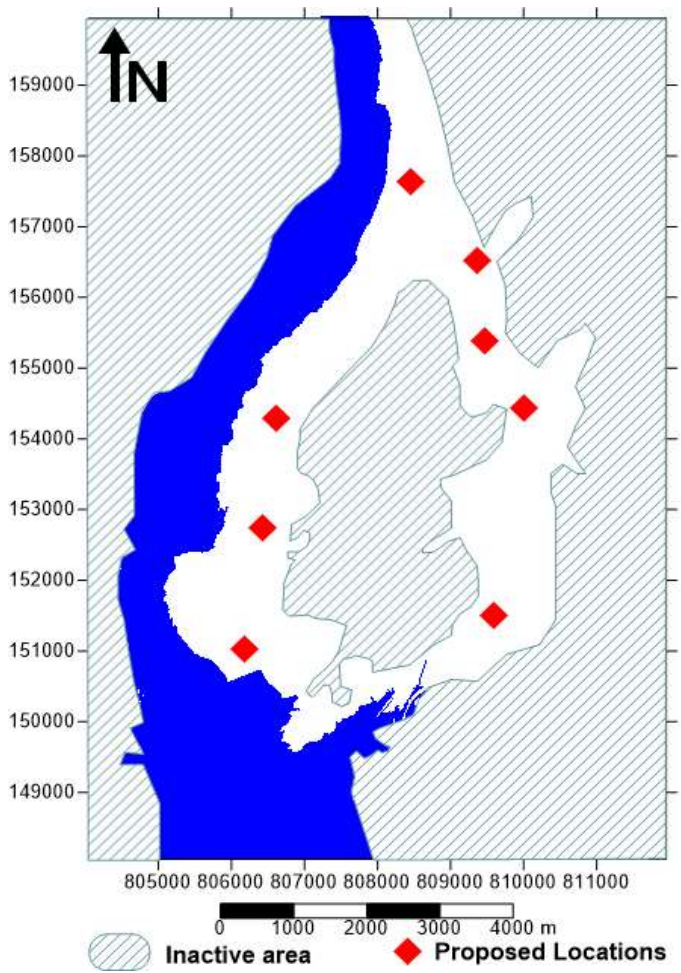

Figure 12. Proposed abstraction sites.

The calibrated model was run to simulate inversing the groundwater rising process, with a total daily extraction of $32,000 \mathrm{~m}^{3}$, to examine the possibility of lowering the groundwater levels back to the conditions before the problem. Predicted lowering rate and distribution obtained from the model runs are checked against and compared to those levels conditions before the problem. Figures 13a, b, c and d illustrate the obtained drawdowns after one year, five years, ten years and for 15 years, respectively. The model results suggest that the proposed dewatering system by pumping wells can successfully lower the groundwater levels to the original conditions before the problem. However, further studies are needed investigate geotechnical impacts of dewatering so that the final design of as an engineered solution can be set and physically implemented. 


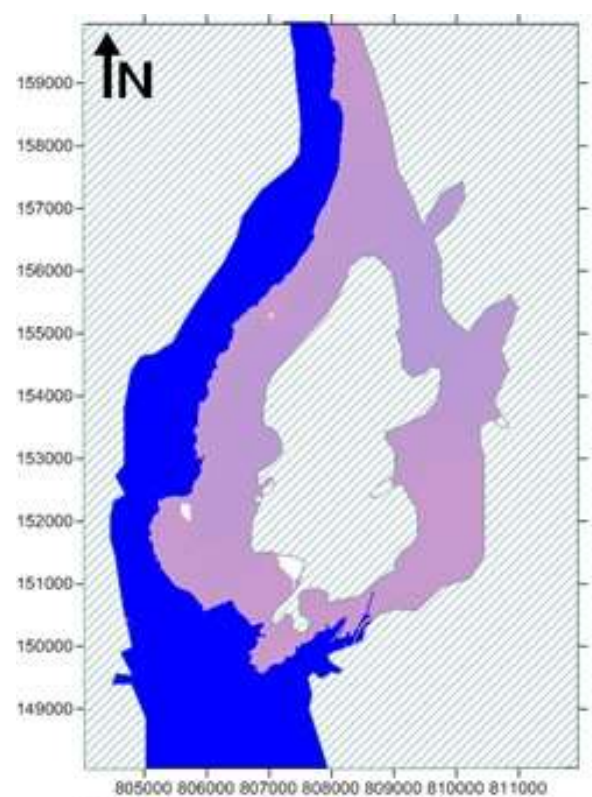

(a) $\div-1$.

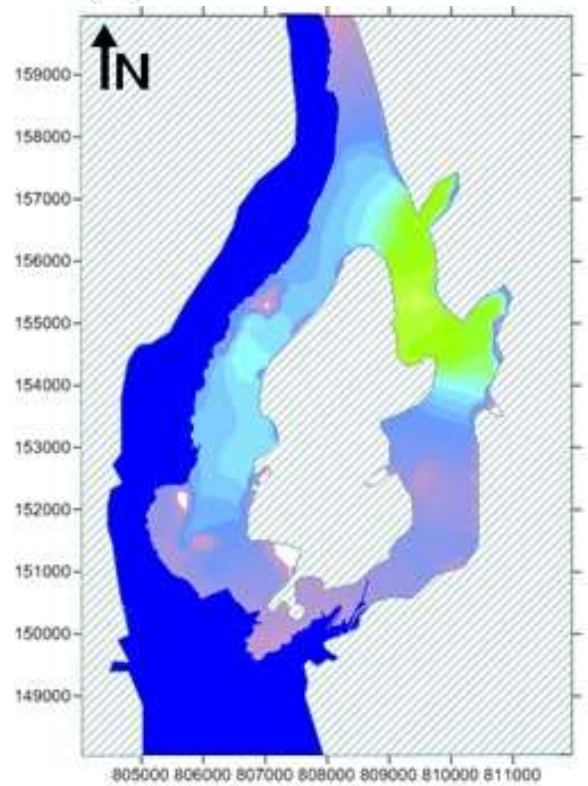

(c)

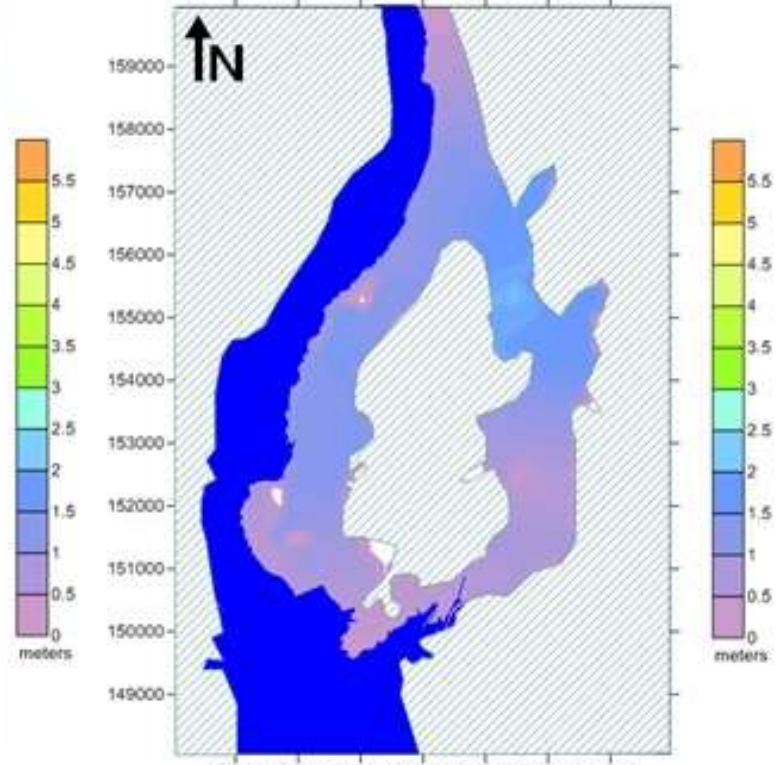

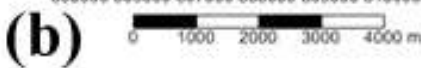

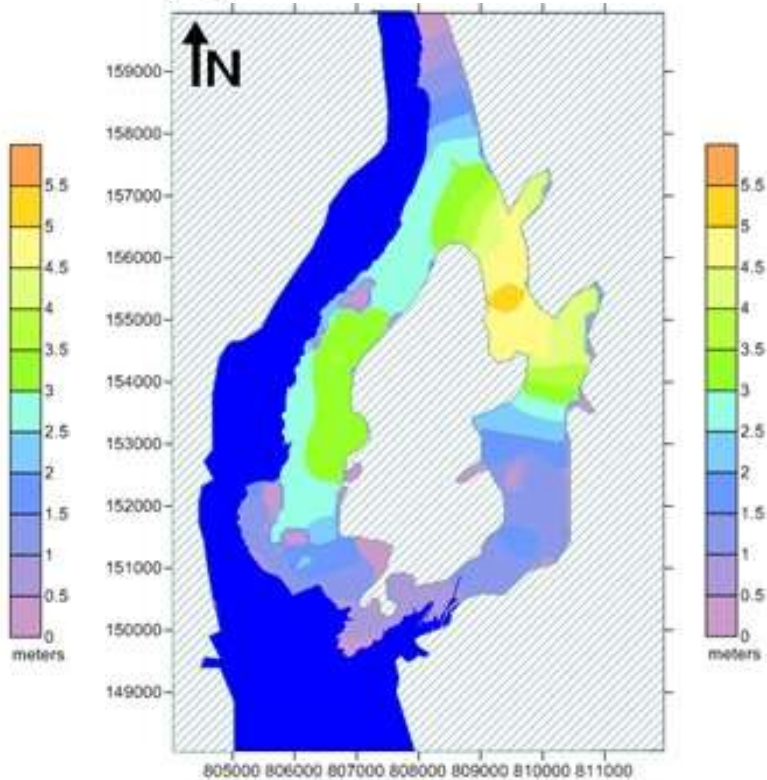

(d)

Figure 13. Drawdowns after: a) 1 year, b) 5 years, c) 10 years, and d) 15 years.

\section{Conclusion and Recommendation}

The city of Aswan is currently suffering from the problem of groundwater rising which is considered as a severe environmental problem hindering development activities in the city. The problem is attributed to alteration of the recharge-discharge conditions in the aquifer system. Investigation and analysis of hydrogeologic conditions in the study area indicate that groundwater rising is mainly attributed to reduction of pumping from both the Kima and El Shalal Area well fields, seepage from excess irrigation water in El Shalal area, seepage from municipal waste water due to growing urbanization in surrounding areas of high relief, and seepage from the fish hatchery bonds in the south part of study area. Changes in groundwater levels were monitored through thirty five observation 
wells, where encountered change in groundwater levels during the period from 2012 to 2017 varied from $0.25 \mathrm{~m}$ to $5.9 \mathrm{~m}$. Chemical and microbiological analyses of surface and groundwater samples indicate increased groundwater salinity due to bad agricultural drainage conditions and the presence of bacteriological pollution due to seepage from the sewage system.

Numerical groundwater flow modeling is used to simulate the hydrogeological conditions of the region. Hence, the calibrated model is run to examine the potential of lowering groundwater levels back to the original conditions before the groundwater rising problem. The proposed solution suggests inversing the groundwater rising process by applying abstraction rates equal to that before the rising levels problem. The adopted solution comprises groundwater abstraction from pumping wells in eight locations distributed in affected areas. The model results suggest that the proposed dewatering system by pumping wells can successfully lower the groundwater levels back to the original conditions before the problem. Difficulties associated with the proposed solution are related to the geomorphological, geological and residential condition in the study area. Geological difficulties are represented by the outcrops and/or the subsurface presence of the granite formation at many locations in the city which impede drilling of the production wells at some places. Also, the residential conditions of the city could affects distribution of pumping wells. Moreover, the pumping rates can negatively affect the stability of the buildings through differential settlement. Therefore, further studies are recommended to evade negative geotechnical impacts so that the final design of an engineered solution can be set and physically implemented.

\section{References}

- Attia ML (1954) Deposits in the Nile Valley and the Delta. Geol Suv. Egypt, Cairo, 356p.

- Barber W, Carr DP. (1981) Water management capabilities of the alluvial aquifer system of the Nile Valley, Upper Egypt. Technical Report No. 11, Water Master Plan, Ministry of Irrigation, Cairo, Egypt; Issawi B, Jux U. (1982) Contribution to the stratigraphy of the Paleozoic rocks in Egypt. Geol. Surv. Egypt, Cairo, V 64 , p. $1-28$

- Hamdan, A. and Abdel Rady A. (2013) Vulnerability of the Groundwater in the Quaternary Aquifer at El Shalal-Kema Area, Aswan, Egypt. Arab Journal of Geoscience, 6, 337-358. http://dx.doi.org/10.1007/s12517-011-0363-y

- Mansur, C.I., and Kaufman, R.I. 1962. Dewatering. In: Leonards G.A. editor, Foundation Engineering, McGraw-Hill Inc.

- RIGW (1988) Hydrogeological Map of Egypt. First Edition, Scale 1:2000,000, Research Institute for Groundwater, Ministry of Public Works and Water Resources, Cairo, Egypt.

- RIGW (2012), "Study Groundwater rising in Aswan City", Research Institute for Groundwater, Ministry Water Resources and Irrigation, Cairo, Egypt.

- $\quad$ RIGW (2017), "Study Groundwater rising in Aswan City", Research Institute for Groundwater, Ministry Water Resources and Irrigation, Cairo, Egypt.

- $\quad$ Said R (1981) The geological evolution of the River Nile. Springer. New York Inc., 151p.

- $\quad$ Said R. (1962) The Geology of Egypt. Elsevier Pub. Co., Amsterdam, New York, p 337.

- Selim S. (1995) Geological and Hydrogeological Studies of the Quaternary Aquifer in Aswan Town Area, Egypt. Egyptian Journal of Geology, 39, 631-645.

- $\quad$ Selim, S.A., Hamdan, A.M. and Rady, A.A. (2014) Groundwater Rising as Environmental Problem, Causes and Solutions: Case Study from Aswan City, Upper Egypt. Open Journal of Geology, 4, 324-341. http://dx.doi.org/10.4236/ojg.2014.47025 